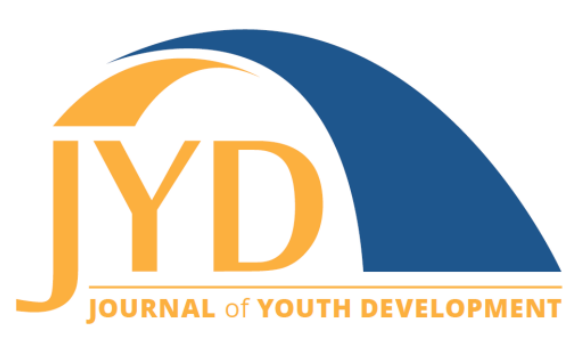

http://jyd.pitt.edu/ | Vol. 15 Issue 6 DOI 10.5195/jyd.2020.868 | ISSN 2325-4017 (online)

\title{
A Comparative Examination of How Program Design Components Influence Youth Leadership-Skill Development
}

\author{
Samantha Bates \\ Texas Christian University, Department of Social Work \\ s.bates@tcu.edu

\section{Dawn Anderson-Butcher} \\ The Ohio State University, College of Social Work \\ anderson-butcher.1@osu.edu

\section{Theresa Ferrari} \\ Ohio 4-H Youth Development, Ohio State University Extension \\ ferrari.8@osu.edu

\section{Christy Clary} \\ Ohio 4-H Youth Development, Ohio State University Extension \\ clary.42@osu.edu
}

\begin{abstract}
A growing interest in how adolescents can prepare for the workforce has contributed to the development of positive youth development (PYD) programs focused on youth leadership. This study explored what mechanisms and design components support leadership skill development among youth participating in 3 different PYD leadership programs. All of these programs involve high school students, have a focus on leadership, and emphasize college and workforce readiness. The aims of the study were to (a) examine what commonalities and differences in program design components contribute to skill development, (b) identify what leadership skills youth develop by participating in PYD leadership programs, and (c) explore what underlying mechanisms youth perceive contribute to their skill development over time. A total of 3 focus groups were conducted, each lasting 90 minutes, with a total of 18 youth (i.e., 6 youth per program). Nvivo, a qualitative software, and thematic analysis were used to distill common and differential themes related to the program design components the participants recognized as integral parts of the programs that contributed to their leadership skill development. Common skills developed across all 3 programs included working in groups, public speaking, and problem solving, yet differences in skills were also reported and linked to differences in program design. Additional findings showed several underlying mechanisms supported leadership skill development among youth participants. Findings can
\end{abstract}

(cc) EY New articles in this journal are licensed under a Creative Commons Attribution 4.0 License. This journal is published by the University Library System, University of Pittsburgh and is cosponsored by the University of Pittsburgh Press. The Journal of Youth Development is the official peer-reviewed publication of the National Association of Extension 4-H Youth Development Professionals and the National AfterSchool Association. 


\section{Program Design Influence on Leadership Skills}

inform the development of effective youth leadership PYD programs, thereby further supporting youth in achieving their goals; avoiding harmful behaviors; and developing the competencies, confidence, and values youth need to successfully transition to adulthood.

Key words: youth leadership, program design, skill development, high school

Leadership skills are highly desired in the contemporary workplace. Liu and colleagues (2020) contend that there are windows of opportunity for leadership development throughout the lifespan, and each stage presents unique opportunities to foster this development. In particular, adolescence is a time for developing many important life skills, including leadership skills. Thus, positive youth development (PYD) programs focused on leadership-skill development are a growing area of research and practice in the field of youth development (Redmond \& Dolan, 2016).

Redmond and Dolan (2016) noted the lack of evidence-based program models for conceptualizing youth leadership program components. However, other scholars have suggested that principles from self-determination theory (Ryan \& Deci, 2017) and relational developmental systems theory (Lerner et al., 2014) can guide youth programming (Bean et al., 2017; Duerden \& Gillard, 2011). Effective youth leadership programs are built on a foundation of PYD principles (Eccles \& Gootman, 2002; Hamilton et al., 2004; Witt \& Caldwell, 2018). Evidence from a variety of sources suggests that PYD programs are ideally suited as a context for developing leadership skills, as they possess three essential elements:

- opportunities to build and master skills using an experiential, "learn by doing" approach (Bean et al., 2017; Redmond \& Dolan, 2016; Subramaniam \& Moncloa, 2010);

- opportunities to apply these skills in meaningful ways in authentic settings (MacNeil \& McClean, 2006; Redmond \& Dolan, 2016; Subramaniam \& Moncloa, 2010); and

- support from adults who facilitate these opportunities (Blanchet-Cohen \& Brunson, 2014; Grossman \& Bulle, 2006; Jones \& Deutsch, 2011; Parkhill et al., 2018; Redmond \& Dolan, 2016; Spencer \& Rhodes, 2014; Subramaniam \& Moncloa, 2010; K. Walker, 2011).

Program leaders are also advised to consider how the group climate facilitates belonging and engagement (Akiva et al., 2013; Blanchet-Cohen \& Brunson, 2014; Dawes \& Larson, 2011; Larson \& Angus, 2011).

Programs can be intentionally designed to attend to developmental needs while promoting desired outcomes, building on strengths, and mitigating risks (J. Walker et al., 2005). 


\section{Program Design Influence on Leadership Skills}

Leadership-skill-development programming and activities are commonly integrated into broader PYD programs in the following ways:

- offering skill-building sessions or partnerships with organizations that connect youth with future college or career options (Bates et al., 2019; Ferrari et al., 2008; Thomas et al., 2017);

- building community-service opportunities into project-based curricula (Lakin \& Mahoney, 2006);

- serving on school or community leadership committees and decision-making bodies (Akiva et al., 2014; Kelsey, 2020; Kelsey \& Fuhrman, 2020; MacNeil \& McClean, 2006; Ramey, 2013);

- giving explicit instruction in teamwork, presentation, and other skills essential for success in the work world (Cochran \& Ferrari, 2009);

- inviting families to share in the learning going on in the school and/or the communitybased program (Eccles \& Gootman, 2002);

- guiding youth as they lead programming to address social issues in their schools and communities (Kirschner \& Ginwright, 2012; Youth Speak Out Coalition \& Zimmerman, 2007); and

- $\quad$ engaging in community-based participatory action research (Anyon et al., 2018; Branquinho et al., 2020; Ozer, 2017; Suleiman et al., 2019).

Although these are common strategies, PYD leadership programs often differ in how they are designed and implemented. Due to these variations, scholars advocate that critical comparisons of youth leadership programs are needed to further understand how their underlying mechanisms, practices, and processes can contribute to the development of specific skills and positive developmental outcomes for youth (Durlak \& DuPre, 2008; Kress, 2006; Larson, 2011; Liu et al., 2020; MacNeil \& McClean, 2006; Mueller et al., 2011; Parkhill et al., 2018; Roth \& Brooks-Gunn, 2016).

Furthermore, research focused on distilling what programs do with whom, in what ways, in what types of settings, and at what level of participation can add to our understanding of what, if any, design elements achieve specific outcomes for youth (Ciocanel et al., 2017; Durlak et al., 2010; Roth \& Brooks-Gunn, 2016). For example, studies may indicate that participants gained leadership skills from their involvement but lack an explanation of how these skills were developed (e.g., Moran et al., 2019). For practitioners, findings can point toward underlying mechanisms that make a difference (Smith et al., 2006), and for what populations, to inform the implementation of effective PYD leadership programs (i.e., getting inside the "black box"; Yohalem \& Wilson-Ahlstrom, 2010). 


\section{Study Purpose and Context}

To explore how youth perceive their leadership-skill development, we solicited youth perspectives on their participation in PYD leadership programs. We recruited youth from three PYD leadership programs within the Ohio 4-H network that used one or more different activities to address leadership-skill development (see aforementioned list of programming and activities). We conducted three 90-minute focus groups with six youth from each PYD leadership program. We used an interpretivist qualitative design and content analysis to understand the experiences of the youth participants (Cohen et al., 2007). Our study was guided by the following research questions: (a) What commonalities and differences in PYD program design components contribute to leadership-skill development? (b) What leadership skills do youth develop when participating in PYD leadership-skill development programs? and (c) What underlying program mechanisms do youth perceive contribute to their leadership-skill development over time? Table 1 summarizes characteristics of program participants, which were provided by program leaders. Next, we provide an overview of each program and demographics gathered from adult leaders.

Table 1. Characteristics of Youth Leadership Program Participants

\begin{tabular}{|l|c|c|c|}
\hline & $\begin{array}{c}\text { Youth Leadership } \\
\text { Academy }\end{array}$ & $\begin{array}{c}\text { Teen Leadership } \\
\text { Council }\end{array}$ & $\begin{array}{c}\text { Job Experience and } \\
\text { Training }\end{array}$ \\
\hline Geographic area & $\begin{array}{c}\text { Regional within state } \\
\text { (30 high schools) }\end{array}$ & Statewide & Local \\
\hline $\begin{array}{l}\text { Number of participants } \\
(2017)\end{array}$ & 57 & 54 & 13 to 17 \\
\hline Age range & 15 to 18 & 14 to 20 & $86 \%$ \\
\hline $\begin{array}{c}\text { Gender } \\
\text { Female }\end{array}$ & $38 \%$ & & $14 \%$ \\
\hline Male & $62 \%$ & $22 \%$ & $100 \%$ \\
\hline $\begin{array}{c}\text { Race } \\
\text { Black/African } \\
\text { American }\end{array}$ & $93 \%$ & Not collected & \\
Multiple races & $5 \%$ & & $70 \%$ qualify for free or \\
White/Caucasian & $2 \%$ & reduced-price lunch \\
\hline Socioeconomic status & $82 \%$ living at or below & Not collected & \\
\hline
\end{tabular}




\section{Youth Leadership Academy}

The Ohio State University (OSU) Learning in Fitness and Education through Sports (LiFEsports) Youth Leadership Academy (YLA) was designed to serve youth who age out of a sport-based PYD summer camp (Bates et al., 2019). Youth engaged in YLA are former LiFEsports campers, now in high school, who wish to remain involved in PYD activities geared toward college and career readiness. All youth who are former LiFEsports participants are accepted into the leadership program after filling out an application. YLA aims to promote leadership-skill development by engaging youth in year-round programming with three intentional phases. Skillbuilding sessions in the first phase are geared toward helping youth prepare for college and the workforce. During the second phase, youth participate in an applied internship experience at the annual LiFEsports Summer Camp, where they serve as junior camp counselors, working approximately 32 hours a week for 4 weeks. During the final phase, youth design a culminating service project to address a social issue in their community.

\section{Teen Leadership Council}

The OSU Extension 4-H Youth Development program has several club-, county-, and state-level leadership opportunities for youth, one of which is the state-level Teen Leadership Council (TLC). The OSU 4-H TLC is comprised of 4-H teens and young 4-H alumni. Youth complete an application and an interview as part of the selection process. Those who apply and participate often have extensive leadership experience based on prior and concurrent roles. The TLC's function is to provide a youth perspective in the planning, implementation, and evaluation of Ohio 4-H programming. Within TLC there are different levels of membership that require varying amounts of involvement. TLC has a tiered participation structure allowing youth to increase their involvement over time. Levels include council member, committee member, committee chair, officer, and junior advisor. All youth participate in youth-led meetings that take place quarterly. Many also engage in peer education programming in their local counties or at national conferences. Committees are set up to allow youth to plan programs, as well as to learn by taking on leadership roles as committee members and committee chairs.

\section{Job Experience and Training Program}

Adventure Central is in a large community center developed through a partnership between OSU Extension's 4-H Youth Development program and Five Rivers MetroParks. Youth participate in after-school programming throughout the year, and in the summer the program supports youth-led service and workforce readiness (Ferrari et al., 2008; Ferrari et al., 2009). To be 


\section{Program Design Influence on Leadership Skills}

eligible, youth must currently attend or have previously attended Adventure Central for afterschool programming. To be selected for the Job Experience and Training (JET) program, youth must complete an application and an interview. JET's focus is on developing youth's $21^{\text {st }}$ century skills through parks and recreation-related career experiences and by providing service to the public. Youth deliver 30 hours of service weekly over an 8-week period, some in paid positions in real-life workforce settings and others as volunteers at one of six MetroParks facilities.

\section{Method}

\section{Participants}

To recruit youth from each of the three PYD programs, we used a convenience sampling approach. We asked program leaders to send recruitment emails to the parents/guardians of the youth participants in their respective program $(N=133)$. Youth who expressed interest received parent permission forms (for those under 18) or consent forms (for those 18 and older) via email. As recommended by Stewart et al. (2007), we aimed to recruit six to 12 youth for each focus group. Once we identified at least six youth interested in participating in the focus groups from each program, we scheduled a 90-minute focus group interview in a public location (one for each program). Program leaders then reached out to other youth in the program and made them aware of the focus group time, date, and location to try to recruit more youth participants. Recruitment efforts resulted in six youth from each program participating in the scheduled focus groups. We collected consent forms and youth signed assent forms prior to each focus group. Participants received a light meal (i.e., pizza, drinks, and dessert) as an incentive for participation. See Table 2 for demographics on the focus group participants. 
Table 2. Youth Demographics of Focus Group Participants

\begin{tabular}{|c|c|c|c|c|}
\hline & $\begin{array}{c}\text { YLA } \\
(n=6)\end{array}$ & $\begin{array}{c}\text { TLC } \\
(n=6)\end{array}$ & $\begin{array}{c}\text { JET } \\
(n=6)\end{array}$ & $\begin{array}{c}\text { Total } \\
(\boldsymbol{N}=\mathbf{1 8})\end{array}$ \\
\hline \multicolumn{5}{|l|}{ Gender } \\
\hline Female & 3 & 5 & 4 & 13 \\
\hline Male & 3 & 1 & 2 & 6 \\
\hline \multicolumn{5}{|l|}{ Race } \\
\hline White, Caucasian & 0 & 5 & 0 & 5 \\
\hline African American/Black & 6 & 0 & 6 & 12 \\
\hline American Indian/Native Alaska & 0 & 0 & 0 & 0 \\
\hline Other & 0 & 1 & 0 & 1 \\
\hline \multicolumn{5}{|l|}{ Age } \\
\hline 15 & 1 & 0 & 0 & 1 \\
\hline 16 & 1 & 2 & 2 & 5 \\
\hline 17 & 4 & 1 & 4 & 9 \\
\hline 18 or older & 0 & 3 & 0 & 3 \\
\hline
\end{tabular}

\section{Procedures}

Two members of the research team (Bates and Clary) conducted one focus group together for a program in which neither had any personal or professional interactions with youth participants. They conducted the other two focus groups independently to avoid interfacing with youth participants with whom they had past affiliations. This decision was made to mitigate risks for respondent bias (i.e., youth telling a familiar researcher what they wanted to hear) and to allow youth to share their experiences openly. Focus group interviews followed a semi-structured interview script covering the following topics:

- motivation for participation in the leadership program;

- gains in knowledge, skills, and information about leadership;

- attitudes, will, and desire to be a leader;

- activities perceived to promote their skill development;

- relationships with peers and adults;

- what youth liked/disliked about programs; and

- how youth perceived what they learned that would benefit them in the future.

Each focus group lasted approximately 90 minutes; they were audio-recorded and later transcribed. All procedures were approved by the OSU Institutional Review Board. 


\section{Data Analysis}

Initially, we reviewed audio recording transcripts for overall content. Using NVivo software, we analyzed the data through inductive content analysis procedures, allowing for the identification of themes and sub-themes within each area through data coding (Guba \& Lincoln, 1994). We made multiple passes through these data, first identifying individual quotations from the focus group interviews that represented single items. These quotations served as the raw primary data. Next, we coded these data into mutually exclusive classifications, and we revised the language to further clarify themes that we identified (as recommended by Corbin \& Strauss, 1990). Then we aimed to distill how each program may contribute to the development of specific knowledge and skills. We looked across the focus groups from the three programs and identified commonalities and differences related to program design components and mechanisms. Throughout the process, categories and themes were reshaped, modified, omitted, and added to other themes until no further categories could be created. To address credibility, dependability, and confirmability, the researchers who conducted the focus group interviews first worked to reach an acceptable level of intercoder agreement. Other team members also reviewed the transcriptions and made notes on themes to work toward agreement. Then all team members discussed the coding process and assisted in triangulating preliminary themes to come to agreement on the final set of themes (Cascio et al., 2019).

Reflexivity is an important component of qualitative inquiry. We identified themes using inductive processes, allowing for youths' experiences and perceptions to frame our understanding of how the programs influenced their skill development. However, biases and the social positionality of those who conducted the focus groups, namely two white female researchers who did not know the youth participants, may have influenced the youth participants' responses. However, both women also are practitioners who are trained to approach youth as experts of their own experiences. Further, the use of focus groups allowed for participants to drive the discussions and share their experiences with little intervention from the researchers.

\section{Results}

\section{Program Design Components}

Through the perspectives of the youth participants, we identified commonalities and differences in program design components specific to their engagement, participation, and skill 
development. Two commonalities in program design that we identified were access to and relationships with caring adult leaders and the opportunity to work with younger youth. Three different program design components were identified, including application and interview processes, working in a real-life workforce setting, and a youth-led decision-making model.

\section{Caring Adult Leaders}

Youth participating in all three PYD leadership programs described access to and relationships with caring adult leaders as an important design component. Youth in YLA described how they knew adult leaders cared about them, but also how adult leaders gave them time to "grow and build the program without a script." Youth in YLA referred to adults as "friends" and "like family." Two examples demonstrated the relationships with adults in the program. One YLA youth leader mentioned,

I like that you know them as people and not counselors. 'Cause a lot of times like if you have a teacher, you know, the teacher it's like "You teach me math." But like as the counselors you know them as like a human being, like a friend almost. Like you see them as family sometimes too. They really understand you because they took the effort to get to know you in the first place. It's like they're just not there to facilitate.

Youth from JET also referred to adult leaders as "family." For example, a male youth leader described his close-knit relationship with a director of the program.

The real reason why I was first initially started in JET is because Mr. A made me. ... I've been here since I was five. When I turned 12, Mr. A was like, "We have leadership positions and I feel like you would fit in it." So, I'm like "No, I don't want to do it," 'cause I wanted to be a kid. . . . That's what was in my head. Mr. A. forced me into the role. So, my first year I went to [park] and when I got there I actually liked the job, so I came back ... I'm just in love with [park] now, so it's just like that's the real reason why I come back, and I also come back because like AC [Adventure Central] is my family, 'cause I don't know nothing else but AC really. So, it's like I want to come back to see my family every summer and every year. That's the real reason why we come back.

Youth perceived that having access to, support from, and encouragement from caring adult leaders, even when it pushed them out of their comfort zone, played a large role in their engagement and participation and in their development of leadership skills. 


\section{Program Design Influence on Leadership Skills}

\section{Working With Younger Youth}

Another common program design component embedded in each of the three PYD leadership programs was the opportunity to work with younger youth, which was described in two ways. First, it was described as a part of the program that created a ladder for youth to obtain entry into leadership positions. The following quote from a JET youth leader describes how working with younger youth is perceived as fun, but also encouraging for younger youth to become future youth leaders.

It's fun to come back and know that you're gonna see either new kids come in and get to know them or kids that you've seen like from six to 12 or six to 10 and see how much they've grown and see how much they've matured and like see them apply . . . talking about applying for JET and I'm like "Okay, like, you do that! You take my spot."

Youth leaders also described working with younger youth as a program design component that helped them practice specific skills, including public speaking, building relationships, controlling emotions, being responsible, having patience, and working in groups.

\section{Interview and Application Process}

Two of the programs, TLC and JET, had an interview and application process. In turn, youth felt they learned specific interviewing skills as a result of these design components. A TLC youth leader reported,

The most impressive part of TLC for me is that if you are interviewing to be an officer, the junior advisors, and junior officers and those who are leaving offices, are the ones who select the teen, and then if you apply to [be a] committee chair, they interview you. So not only if you are interviewing do you gain skills and get to practice, but you also get to see the other side and think, "What do I look for in this person?" and "What do I want for this position?" and so it gives you such a well-rounded idea of what you are walking into.

Several youths mentioned not being accepted into the JET program upon their first attempt. These youth perceived the opportunity to receive feedback and have another opportunity to succeed as a program component that greatly influence their self-talk, and in turn, their resilience to try again. As a JET youth leader described,

So, I turned in . . . my first application when I was 12. I didn't get it. I didn't get it. And after all that stuff I did, the interview and everything, and I felt like I actually got it. I was devastated. Oh, I was so devastated. And I came back the next year and I thought I wasn't gonna get it again, and I was like "I'll just turn 
this in." You know, I put up my all into that application, though. But when I found out I got it, Ms. J brought me out to the hallway, and I remember her saying "You got it." I was thinking, "Really, me?" Like I was so excited! . . . I learned so much in that first year alone.

\section{Internship in a Real-Life Workforce Setting}

The JET program allowed youth to participate in real-life workforce settings. One JET youth leader shared,

I learned how to garden, prune flowers, gardening stuff, maintain the park. . . . I worked basically a 9 to 5 . . so it was like an actual job. Like I would have to be actually like an adult and wake up, wake my parents up so I can get to work on time. . . . it was actually like how I felt was my real job like what I wanted to do for the rest of my life.

As a result of participating in internships that took place in real-life workforce settings, youth in JET also reported greater career readiness, including awareness of their own work ethic, as well as the importance of responsibility and accountability.

\section{Youth-Led Decision-Making Model}

TLC used a youth-led decision-making design approach that participants felt influenced their skill development. They described how all their activities and meetings were led by the youth leaders, which created opportunities for these youth to engage in building skills such as public speaking, problem-solving, and working in groups. One TLC youth leader described how the youth-led approach helped youth learn valuable skills. This youth leader stated,

I think they are letting us grow because they aren't over our shoulder like tell us "this has to get done." So, they are like letting you be you, and so when you go out to college you are ready for the real world. With 4- $H$ being a youth-led organization, adults like aren't supposed to be involved. Like yes, they are there to advise us, but they are not supposed to be the ones running the meetings, and in order to have that opportunity they can't be involved, and it allows us to grow as people.

\section{Leadership-Skill Development}

We distilled several common themes from youths' reports of the skills they developed. First, youth in all three programs described greater understanding, knowledge, or awareness of the role of a leader. They described examples of understanding how leaders gain trust of others, 
Program Design Influence on Leadership Skills

how leaders make decisions, how leaders care about those they are working with, and how leaders listen. One quotation from a youth leader in YLA demonstrated how the program helped him think about leadership. He stated,

I like putting it like this ... there are a lot of people in a hole and one person gets out. I feel like leadership is having the ability to not only get out but to bring the other people up out of the hole with you. So, like knowing how to get it and then teach it to others. Like taking control of the situation without not necessarily talking or without sometimes not being silent but just being able to help others along the way so we can all get to the same destination together. Youth mentioned how participation helped them learn three additional skills: working in groups, problem-solving, and public speaking.

We also identified five differences in relation to knowledge and skills. As discussed previously, the TLC and JET programs had application and interview processes. Youth in these programs discussed learning skills such as how to interview for a job. Another difference that youth in YLA and JET reported was learning how to write a resume and learning about responsibility; they also felt more knowledgeable about different careers. Youth in JET also reported links between their internships in real-life workforce settings and their knowledge and awareness of the importance of work ethic and accountability. In Table 3 we summarize program design components and knowledge and skills described by youth in each program. 
Table 3. Summary of Results on Program Design Components, Knowledge, and Skills

\begin{tabular}{|c|c|c|c|}
\hline Program design component & YLA & TLC & JET \\
\hline Caring adult leaders & $x$ & $x$ & $x$ \\
\hline Working with younger youth & $x$ & $x$ & $x$ \\
\hline Application and interview process & & $x$ & $x$ \\
\hline Youth-led decision-making model & & $X$ & \\
\hline Internship in real-life workforce setting & & & $x$ \\
\hline \multicolumn{4}{|l|}{ Knowledge and skills } \\
\hline Understanding the role of a leader & $x$ & $x$ & $x$ \\
\hline Working in groups & $\mathrm{x}$ & $x$ & $x$ \\
\hline Problem-solving & $x$ & $x$ & $x$ \\
\hline \multicolumn{4}{|l|}{ Communication skills } \\
\hline Public speaking & $x$ & $x$ & $\mathrm{X}$ \\
\hline Interviewing & & $x$ & $x$ \\
\hline \multicolumn{4}{|l|}{$\underline{\text { Career readiness }}$} \\
\hline Writing a resume & $x$ & & $x$ \\
\hline Knowledge of different careers & $x$ & & $\mathrm{X}$ \\
\hline Work ethic and accountability & & & $x$ \\
\hline Responsibility & $x$ & & $x$ \\
\hline Patience and controlling emotions & $x$ & & \\
\hline
\end{tabular}

\section{Underlying Mechanisms}

Across the focus group interviews, we identified seven common underlying mechanisms indicating links between program design components and perceptions of skill development.

\section{Designated Time and Space to Have Fun, Build Relationships, and Meet New People}

Youth from each program gave examples, such as starting sessions with icebreakers or fun activities like line dancing, that helped make their experiences in the programs enjoyable and created space for peers to interact and introduce themselves safely to others. A TLC youth leader mentioned, "One thing we are known for, [pause] you know you are going to play at least three icebreakers or line dance [lots of laughter from entire focus group]." Another example was from a JET youth leader who stated,

The first day everybody's like "Let's get to know each other. " Not even the first day. We have an orientation week of nothing but activities and getting to know 
each other. Going out, doing different things. . . . We would share our stories from each of our groups, 'cause each of our groups are very different.

Incorporating time and space for youth leaders to have fun where they can connect, laugh, and find common ground appeared to be an increasingly important mechanism supportive of youth coming to the programs and remaining involved.

\section{Safe, Supportive, Accepting, and Motivating Climate}

Youth from all three programs reported feeling "supported" and "accepted," and a sense of high expectations from adult leaders and other youth in the programs. Speaking about the adult leaders, a TLC youth leader mentioned, "They don't judge you about anything. They don't care about your background. They are here to have fun and hang out with you anyways." A youth leader in YLA stated,

I really see that I've learned in my everyday life. The relationships that I've created with people I value, especially with the counselors . . . it's like they never pushed me away. So, it's like a place that I know I can always come back to and ... the experiences that I've made have helped me grow as a person and develop while going through my teenage years and getting ready for life.

Youth in each program described that their backgrounds and decisions were not judged, but rather all relationships with others were considered valuable opportunities to maximize selfgrowth and feel acceptance.

\section{Developmentally Appropriate Level of Challenge}

Youth reported their PYD programs created an environment where they were able to engage in developmentally appropriate challenges, such as moving from being a camper to working with younger youth or working in a job out in the community. Youth in each of the programs recognized that their engagement over time (e.g., either as former campers or members of committees) helped them develop foundational and relational skills, but also stated new challenges that came with age and experience were presented via scaffolding mechanisms within the programs that led to into internships, jobs, or new roles on committees. One JET youth leader described,

It was about 25 kids in my first group I had, and it was the biggest group here, and I was only 13, and I'm like "I have all this responsibility, I'm the leader and I have to watch over all of these kids. "And year after year I grew some, I grew some, I grew some, and . . I got more educated and I gained more skills, and I took this from this 
Journal of Youth Development | http://jyd.pitt.edu/ | Vol. 15 Issue 6 DOI 10.5195/jyd.2020.868

Program Design Influence on Leadership Skills

person and this from this person. I accepted criticism and all of that until I grew into who I am today, and I will take that with me into the future.

\section{Access to New Experiences and Places}

Youth reported that access to new experiences was a reason they enjoyed coming to and participating in the PYD programs. Youth from YLA and JET described how new experiences such as kayaking, going on college visits, and attending career visits helped them learn new things and have fun together. One example shared by a TLC youth leader describes how the 4-H program connects youth to new experiences.

TLC brings the opportunities to youth rather than youth having to go out and find opportunities. So once youth join the State Board, they are given an insane amount of opportunities that are absolutely amazing. My personal favorite is the National 4-H Conference. . . . It was an amazing experience that I was able to grow from.

\section{Experiential Opportunities and Activities to Practice Skills}

Youth in all three PYD programs reported involvement in experiential learning opportunities and activities. They described how teaching younger youth, either as junior counselors or working on committees, gave them opportunities to practice their communication skills, especially public speaking in front of groups. Youth also mentioned that the opportunity to learn in an environment where there were fewer consequences if and when they made a mistake made them more likely to try new things. Fewer consequences also appeared to make youth feel more willing to try new things and process failing because supports were in place to help them work on their skills. One youth leader in JET mentioned what he liked about the program.

So, it's basically to teach people how to get a job and what to do if you're in a job, and there's kind of like a training process. Like if you mess up here it . . . consequences aren't as bad as if you were to mess up at a real job.

Youth in TLC and YLA shared similar statements relating to how adults or older counselors were available to support them if they failed, and they described several examples where adults or peers encouraged them to try again.

\section{Sibling and Peer Engagement}

Youth in all three programs discussed the involvement of siblings and older peers. Youth reported wanting to participate because an older brother or sister or an older youth had a good experience. A TLC youth leader mentioned, "Both of my siblings were on Ambassadors, so I 


\section{Program Design Influence on Leadership Skills}

decided to do that and then when I did, I realized it was really amazing." Another JET youth leader described why he wanted to be in the program:

Mine was definitely legacy. I know I keep talking about my siblings, but not just my siblings. . . . I feel like we have generational. . . . JET's like all I've seen. I've seen like my brother's group, . . . and then they passed it down to my sister and their whole generation were JET teens while my brother was now the group leader, so it was like they were the group leaders now.

\section{Sense of Pride}

Engagement and participation also centered on a sense of pride youth felt when participating in the programs. Youth mentioned that their engagement was facilitated by wanting to "help others" or "be good role models." Others mentioned older youth who "helped me when I was in the program" or a desire to "make my mom proud." One youth in JET described wanting to make the director of the Adventure Central and his mom proud. He described,

My mom is very proud of me to be in this program. One, is because Mr. A was like a father figure, so it was like my dad passed away when I was younger, . . . like she knew. . . she had three boys. She knew coming up we all were gonna probably head down a bad road, so sending us here was like giving us a second chance before we even started. . . . she was encouraged 'cause at first I didn't want to come here. I was like, "Man, I gotta come here every day after school?" It was just like another couple hours of school. . . . but once I started coming here it was like she started seeing my grades improve. She started seeing me communicate more. So, she felt like AC was . . . basically like their motto, "AC is the place to be."

A sense of pride in being leaders to others, opportunities to be acknowledged, and a positive status were important mechanisms to engage youth in each of the three PYD programs.

\section{Discussion}

Involvement in PYD programs focused on leadership-skill development may be highly protective and supportive of positive outcomes for youth. Youth in all three of the PYD leadership programs reported developing important skills and knowledge associated with leadership. Our results align with and lend support to youth leadership programming based on PYD principles (Eccles \& Gootman, 2002; Hamilton et al., 2004; Witt \& Caldwell, 2018). There were several common design components that appeared to facilitate positive leadership outcomes for youth. These findings are in alignment with studies showing that the "Big Three," including positive 


\section{Program Design Influence on Leadership Skills}

relationships, skill building, and leadership activities, are important components of effective PYD programs (Lerner et al., 2014). We found that caring adult leaders and the opportunity to work with younger youth facilitated skill development for youth participants. Youth reported that adult figures knew their names, knew about their interests, and were available and willing to provide emotional support like friends and family.

Further, caring adults were described as those who provided instrumental supports such as information, content, and structure within the programs. These results also align with findings noting that relationships that facilitate both instrumental and emotional support for youth are increasingly protective (Eccles \& Gootman, 2002; Grossman \& Bulle, 2006; Jones \& Deutsch, 2011; Spencer \& Rhodes, 2014; K. Walker, 2011). Our findings also align with those from America's Promise Alliance (2020), which show that young people with formal and informal mentors in their lives are more likely to stay in school, enroll in college, become active in sports, become leaders, and pursue higher goals than those who do not have mentoring in their lives. As a result, we argue that ensuring youth have opportunities to build relationships with caring adult figures is critical to successful PYD programming and also to the development of leadership skills. These practices are especially important given the detrimental impacts of negative interactions (Albright \& Ferrari, 2010; Buehler et al., 2020; Dworkin \& Larson, 2007).

We also found that the program design component where youth work with younger youth and experience a ladder approach to attaining leadership positions aligns with past work in the PYD field. Ferrari and Risch (2013) found that when youth have opportunities to grow into and grow from their roles in PYD programs, participants achieved positive outcomes. Cochran and Ferrari (2009) described how a natural progression from participant to teen leader, a strategy they termed "growing your own" (p. 19), facilitated skill development and workplace readiness.

Differences in program design components included the application and interview processes that appeared to influence youth perceptions of their interviewing skills. Further, the application and interview processes may have influenced other personal or social skill outcomes. Several youths described not gaining access to the program on their first attempt. Youth reported either feeling encouraged to try again to make their program leaders or families proud or to try again because they wanted to follow in their siblings' or older peers' footsteps. The application and interview design component, along with these mechanisms underlying their motivations to reapply, may facilitate conditions where youth face and overcome adversity. For example, the application and interview process may not only help youth develop interviewing skills, but may also instill perseverance for long-term goals. 
Two other design components differed among programs. The JET program offered internships in real-life workforce settings. Among the youth in all three programs, youth in JET were those who more frequently reported gaining knowledge about the importance of work ethic and accountability. Hence, programs that place youth in workforce settings may be those more likely to contribute to career readiness outcomes and the development of $21^{\text {st }}$ century skills. TLC's distinct design component was the youth-led decision-making model. Youth in TLC described feeling empowered and presented with strong communication skills likely due to their role in providing their perspectives on the organization's programming. The extent to which programs emphasize inclusion of the youth voice appears to be a positive element to consider when intentionally designing youth leadership programs (Cater et al., 2013; Serido et al., 2011).

Participation in these PYD leadership programs helped youth develop prosocial skills, such as communication and problem-solving skills; participation also supported youth in gaining practical components of career readiness (see Table 3). These outcomes are important given the rising importance of career readiness and nonacademic skills in the workplace (Burrus et al., 2013; Deming, 2017; Lerner et al., 2006; Lippman et al., 2015). To date, many employers note that new entrants to the workforce arrive unprepared (Casner-Lotto \& Barrington, 2006). Hence programs that allow youth to practice skills prior to entry into the workforce and center their designs around a "value-added" approach (Cochran \& Ferrari, 2009) may help address gaps in readiness voiced by employers. MacNeil and McClean (2006) argue that youth are often absent from literature focused on leadership theory, leadership development, or leadership practice. There is a continued call for research that examines how these experiences might be structured, implemented, and measured via participation in PYD programs (MacNeil \& McClean, 2006; Redmond \& Dolan, 2016). Our study contributes by examining underlying mechanisms that promote the development of leadership skills that maybe useful to practitioners (i.e., interviews, internships, youth-led committees, ladder design where youth lead younger youth).

\section{Implications}

PYD leadership programs such as those studied here may promote positive outcomes for youth (e.g., college and career readiness, leadership). These findings have several practical implications for PYD leaders. Findings point to the critical role of employing caring and supportive adult leaders in youth-serving contexts. A potential application of this finding is to intentionally train adult leaders in recognizing and implementing components of effective PYD practice. Trainings should emphasize giving youth workers the tools, time, space, and strategies 


\section{Program Design Influence on Leadership Skills}

to reinforce positive behaviors and to build relationships. Adult leaders can also be encouraged to capitalize on times when youth make mistakes and to use these experiences as teachable moments to help youth master new skills. Through an intentional focus on the training of adult leaders, programs can seek to cultivate climates where youth are exposed to opportunities, feel empowered to try things, and engage in activities that further develop their skills.

Second, designing programs that have multiple levels of youth involvement appears to be important to the development of leadership skills. The multiple levels of involvement create a climate that keeps youth engaged, keeps youth working toward higher leadership positions, and engages youth in appropriate levels of challenge. Youth in the focus groups liked working toward something and setting goals in the program. Program leaders can create hierarchies within their programs or partner with other PYD contexts to provide opportunities for youth to stay engaged over time.

One final implication speaks to the need for advocacy and equitable access in the field of PYD. To meet the growing demands of today's economy, there is a need in communities, especially those serving at-risk youth, to offer PYD programming. In our study, two programs served a population of youth who identified as predominantly racial minorities and one program served a large number of youth living in poverty. These youth are notably from groups that are often underrepresented in higher education and those more likely to experience the intergenerational effects of poverty, including higher rates of unemployment (de Brey et al., 2019). Our findings support the notion that PYD leadership programs may be one long-term, protective strategy for leaders and policymakers to invest in to address issues of inequity in life-skill and social-skill development, especially to mitigate long-term social and economic risks for adolescents.

\section{Limitations}

This study is not without limitations, with the primary issue being transferability to other youth programs. These three programs may be unique in their program designs. The sample size was relatively small; however, Guest et al.'s (2016) study determined that between three to six focus groups may be sufficient to identify relevant themes. Another limitation is that youth included in the study may potentially be only those who had positive experiences or felt motivated to participate. Although difficult, researchers can attempt to interview those who do not persist in leadership programs to further understand their experiences and what components are not conducive to positive outcomes (e.g., see Albright \& Ferrari, 2010; Harrington et al., 2011). In the future, researchers can conduct mixed methods studies with 
youth from various demographic backgrounds, youth in other PYD programs, and program leaders; review curriculum documents; and conduct observations to triangulate the data regarding intentionality of program design, underlying mechanisms, and program outcomes.

\section{Conclusion}

Young people can attain several individual and societal benefits when they have experiences and opportunities to become more successful leaders. By better understanding which components and mechanisms are effective in promoting positive outcomes in PYD leadershipskill-development programs, program coordinators, clinicians, social workers, teachers, and PYD staff also can use the information gleaned from this study to design curricula, interventions, and programs that better assist youth in developing $21^{\text {st }}$ century and nonacademic skills that can help them successfully transition into adulthood and life outside of school.

\section{References}

America's Promise Alliance. (2020). The five promises: Caring adults. https://www.americaspromise.org/promise/caring-adults

Akiva, T., Cortina, K. S., Eccles, J. S., \& Smith, C. (2013). Youth belonging and cognitive engagement in organized activities: A large-scale field study. Journal of Applied Developmental Psychology, 34(5), 208-218. https://doi.org/10.1016/j.appdev.2013.05.0

Akiva, T., Cortina, K. S., \& Smith, C. (2014). Involving youth in program decision-making: How common and what might it do for youth? Journal of Youth and Adolescence, 43, 1844-1860. https://doi.org/10.1007/s10964-014-0183-y

Albright, M. D., \& Ferrari, T. M. (2010). "Push" and "pull": A qualitative study of factors that contribute to older youth leaving the 4-H program. Journal of Youth Development, 5(3), 55-74. https://doi.org/10.5195/jyd.2010.209

Anyon, Y., Bender, K., Kennedy, H., \& Dechants, J. (2018). A systematic review of youth participatory action research (YPAR) in the United States: Methodologies, youth outcomes, and future directions. Health Education and Behavior, 45(6), 865-878. https://doi.org/10.1177/1090198118769357

Bates, S., Anderson-Butcher, D., Niewoehner-Green, J., \& Provenzano, J. (2019). Exploration of a college and career readiness leadership program for urban youth. Journal of Youth Development, 14(3), 160-182. https://doi.org/10.5195/jyd.2019.664 
Journal of Youth Development | http://jyd.pitt.edu/ | Vol. 15 Issue 6 DOI 10.5195/jyd.2020.868 Program Design Influence on Leadership Skills

Bean, C., Harlow, M., \& Kendellen, K. (2017). Strategies for fostering basic psychological needs support in high quality youth leadership programs. Evaluation and Program Planning, 61, 76-85. https://doi.org/10.1016/j.evalprogplan.2016.12.003

Blanchet-Cohen, N., \& Brunson, L. (2014). Creating settings for youth empowerment and leadership: An ecological perspective. Child \& Youth Services, 35(3), 216-236.

https://doi.org/10.1080/0145935X.2014.938735

Branquinho, C., Tomé, G., Grothausen, T., \& Gaspar de Matos, M. (2020). Community-based youth participatory action research studies with a focus on youth health and well-being: A systematic review. Journal of Community Psychology, 48, 1301-1315. https://doi.org/10.1002/jcop.22320

Buehler, K., Sánchez, B., Vaclavik, D., Rodriguez, \& Gray, T. (2020). Rules of disengagement: Negative relationships and interactions between adults and youth. Youth \& Society, 52(6), 1033-1056. https://doi.org/10.1177/0044118X18793157

Burrus, J., Jackson, T., Xi, N., \& Steinberg, J. (2013). Identifying the most important $21^{\text {st }}$ century workforce competencies: An analysis of the Occupational Information Network (O*NET). ETS Research Report Series [ETS-RR-13-21]. http://onlinelibrary.wiley.com/doi/10.1002/j.23338504.2013.tb02328.x/epdf

Cascio, M. A., Lee, E., Vaudrin, N., \& Freedman, D. A. (2019). A team-based approach to open coding: Considerations for creating intercoder consensus. Field Methods, 21(2), 116-130. https://doi.org/10.1177/1525822X19838237

Casner-Lotto, J., \& Barrington, L. (2006). Are they really ready to work? Employers' perspectives on the basic knowledge and applied skills of new entrants to the $21^{\text {st }}$ century U.S. workforce. Conference Board. http://www.conferenceboard.org/pdf free/BED-06-Workforce.pdf

Cater, M., Machtmes, K., \& Fox, J. E. (2013). A phenomenological examination of context on adolescent ownership and engagement rationale. The Qualitative Report, 18, Article 31, 1-13. http://www.nova.edu/ssss/QR/QR18/cater31.pdf

Ciocanel, O., Power, K., Eriksen, A., \& Gillings, K. (2017). Effectiveness of positive youth development interventions: A meta-analysis of randomized controlled trials. Journal of Youth and Adolescence, 46, 483-504. https://doi.org/10.1007/s10964-016-0555-6

Cochran, G., \& Ferrari, T. M. (2009). Preparing youth for the $21^{\text {st }}$ century knowledge economy: Youth programs and workforce preparation. Afterschool Matters, 8, 11-25. http://www.robertbownefoundation.org/pdf files/2009 asm spring.pdf

Cohen, L., Manion, L., \& Morrison, K. (2007). Research methods in education (6 $6^{\text {th }}$ ed.). Routledge/Taylor \& Francis Group.

Corbin, J. M., \& Strauss, A. (1990). Grounded theory research: Procedures, canons, and evaluative criteria. Qualitative Sociology, 13(1), 3-21. https://doi.org/10.1007/BF00988593 
Journal of Youth Development | http://jyd.pitt.edu/ | Vol. 15 Issue 6 DOI 10.5195/jyd.2020.868

Program Design Influence on Leadership Skills

Dawes, N. P., \& Larson, R. W. (2011). How youth get engaged: Grounded-theory research on motivational development in organized youth programs. Developmental Psychology, 4オ1), 259269. https://doi.org/10.1037/a0020729

de Brey, C., Musu, L., McFarland, J., Wilkinson-Flicker, S., Diliberti, M., Zhang, A., Branstetter, C., \& Wang, X. (2019). Status and trends in the education of racial and ethnic groups 2018 (NCES 2019-038). National Center for Education Statistics. https://eric.ed.gov/?id=ED592833

Deming, D. J. (2017). The growing importance of social skills in the labor market. The Quarterly Journal of Economics, 132(4), 1593-1640. https://doi.org/10.1093/qje/ajx022

Duerden, M. D., \& Gillard, A. (2011). An approach to theory-based youth programming. New Directions for Youth Development, S1, 39-53. https://doi.org/10.1002/yd.418

Durlak, J. A., \& DuPre, E. P. (2008). Implementation matters: A review of research on the influence of implementation on program outcomes and the factors affecting implementation. American Journal of Community Psychology, 41, 327-350. https://doi.org/10.1007/s10464-008-9165-0

Durlak, J. A., Weissberg, R. P., \& Pachan, M. (2010). A meta-analysis of after-school programs that seek to promote personal and social skills in children and adolescents. American Journal of Community Psychology, 45(3-4), 294-309. https://doi.org/10.1007/s10464-010-9300-6

Dworkin, J., \& Larson, R. (2007). Adolescents' negative experience sin organized youth activities. Journal of Youth Development, 1(3), 44-62. https://doi.org/10.5195/jyd.2007.373

Eccles, J. S., \& Gootman, J. A. (Eds.). (2002). Community programs to promote youth development. National Academies Press.

Ferrari, T. M., Arnett, N., \& Cochran, G. (2008). Preparing teens for success: Building $21^{\text {st }}$ century skills through a 4-H work-based learning program. Journal of Youth Development, 3(1), 27-44. https://doi.org/10.5195/jyd.2008.317

Ferrari, T. M., Lekies, K. S., \& Arnett, N. (2009). Opportunities matter: Exploring youths' perspectives on their long-term participation in an urban $4-\mathrm{H}$ youth development program. Journal of Youth Development, 4(3), 22-40. https://doi.org/10.5195/jyd.2009.249

Ferrari, T. M., \& Risch, L. S. (2013). Exploring 4-H camp counseling as a context for developing responsibility. Abstract of a presentation at the American Camp Association Camp Research Symposium, Dallas, TX. Retrieved from http://www.acacamps.org/research/connect/researchsymposiums

Grossman, J. B., \& Bulle, M. J. (2006). Review of what youth programs do to increase the connectedness of youth with adults. Journal of Adolescent Health, 39, 788-799. https://doi.org/10.1016/j.jadohealth.2006.08.004

Guba, E. G., \& Lincoln, Y. S. (1994). Competing paradigms in qualitative research. In N. K. Denzin \& Y. S. Lincoln (Eds.), Handbook of qualitative research (pp. 105-117). Sage. 
Journal of Youth Development | http://jyd.pitt.edu/ | Vol. 15 Issue 6 DOI 10.5195/jyd.2020.868 Program Design Influence on Leadership Skills

Guest, G., Namey, E., \& McKenna, K. (2017). How many focus groups are enough? Building an evidence base for nonprobability sample sizes. Field Methods, 29(1), 3-22.

\section{https://doi.org/10.1177/1525822X16639015}

Hamilton, S. F., Hamilton, M. A., \& Pittman, K. (2004). Principles for youth development. In S. F. Hamilton \& M. A. Hamilton (Eds.), The youth development handbook: Coming of age in American communities (pp. 3-22). Sage.

Harrington, R., Sheehan, T., \& Blyth, D. (2011). Examining the reasons and relationships between why youth join, stay in, and leave 4-H. Journal of Youth Development, 6(2), 39-47. https://doi.org/10.5195/jyd.2011.186

Jones, J. N., \& Deutsch, N. L. (2011). Relational strategies in after-school settings: How staff-youth relationships support positive development. Youth \& Society, 43(4), 1381-1406.

\section{https://doi.org/10.1177/0044118X10386077}

Kelsey, K. D. (2020). The sharpening stone: A phenomenological study of the impact of a 4-H state-level leadership role on youth leadership and life skills development. Journal of Human Sciences and Extension, 8(1), 1-16. https://www.jhseonline.com/article/view/997

Kelsey, K. D., \& Fuhrman, N. E. (2020). Leadership and life skills development among 4-H state-level youth leaders. Journal of Human Sciences and Extension, 8(2), 15-27. https://www.jhseonline.com/article/view/1049

Kirschner, B., \& Ginwright, S. (2012). Youth organizing as a developmental context for African American and Latino adolescents. Child Development Perspectives, 6(3), 288-294. https://doi.org/10.1111/j.1750-8606.2012.00243.x

Kress, C. A. (2006). Youth leadership and youth development: Connections and questions. New Directions for Youth Development, 109, 45-56. https://doi.org/10.1002/yd.154

Lakin, R., \& Mahoney, A. (2006). Empowering youth to change their world: Identifying key components of a community service program to promote positive development. Journal of School Psychology, 44(6), 513-531. https://doi.org/10.1016/j.jsp.2006.06.001

Larson, R. W. (2011). Positive development in a disorderly world. Journal of Research on Adolescence, 21(2), 317-334. https://doi.org/10.1111/j.1532-7795.2010.00707.x

Larson, R. W., \& Angus, R. (2011). Pursuing paradox: The role of adults in creating empowering settings for youth. In M. Aber, K. Maton, \& E. Seidman (Eds.), Empowering settings and voices for social change (pp. 65-93). Oxford University Press.

Lerner, R. M., Alberts, A. E., Jelicic, H., \& Smith, L. M. (2006). Young people as resources to be developed: Promoting positive youth development through adult-youth relations and community assets. In E. G. Clary \& J. E. Rhodes (Eds.), Mobilizing adults for positive youth development: Strategies for closing the gap between beliefs and behaviors (pp. 19-39). Springer. 
Lerner, R. M., Wang, J., Chase, P. A., Gutierrez, A. S., Harris, E. M., Rubin, R. O., \& Yalin, C. (2014). Using relational developmental systems theory to link program goals, activities, and outcomes: The case of the 4-H Study of Positive Youth Development. New Directions for Youth Development, 144, 17-30. https://doi.org/10.1002/yd.20110

Lippman, L. H., Ryberg, R., Carney, R., \& Moore, K. A. (2015). Workforce connections: Key "soft skills" that foster youth workforce success: Toward a consensus across fields. Child Trends. https://www.childtrends.org/wp-content/uploads/2015/06/2015-24WFCSoftSkills1.pdf

Liu, Z., Venkatesh, S., Murphy, S. E., \& Riggio, R. E. (2020). Leader development across the lifespan: A dynamic experiences-grounded approach. The Leadership Quarterly. https://doi.org/10.1016/j.leaqua.2020.101382

MacNeil, C. A., \& McClean, J. (2006). Moving from "youth leadership development" to "youth in governance": Learning leadership by doing leadership. New Directions for Youth Development, 109, 99-106. https://doi.org/10.1002/yd.157

Moran, L., Bunch, J. C., \& Cater, M. (2019). 4-H state leadership boards: Measuring leadership life skills and youth-adult relationships. Journal of Human Sciences and Extension, 71 ), 68-78. https://www.jhseonline.com/article/view/807

Mueller, M. K., Phelps, E., Bowers, E. P., Agans, J. P., Urban, J. B., \& Lerner, R. M. (2011). Youth development program participation and intentional self-regulation skills: Contextual and individual bases of pathways to positive youth development. Journal of Adolescence, 34(6), 1115-1125. https://doi.org/10.1016/j.adolescence.2011.07.010

Ozer, E. J. (2017). Youth-led participatory action research: Overview and potential for enhancing adolescent development. Child Development Perspectives, 11(3), 173-177. https://doi.org/10.1111/cdep.12228

Parkhill, A., Deans, C. L., \& Chapin, L. A. (2018). Pre-leadership processes in leadership training for adolescents. Children and Youth Services Review, 88, 375-379. https://doi.org/10.1016/j.childyouth.2018.03.033

Ramey. H. L. (2013). Organizational outcomes of youth involvement in organizational decision making: A synthesis of qualitative research. Journal of Community Psychology, 41(4), 488-504.

\section{https://doi.org/10.1002/jcop.21553}

Redmond, S., \& Dolan, P. (2016). Toward a conceptual model of youth leadership development. Child \& Family Social Work, 21, 261-271. https://doi.org/10.1111/cfs.12146

Roth, J. L., \& Brooks-Gunn, J. (2016). Evaluating youth development programs: Progress and promise. Applied Developmental Science, 20(3), 188-202. https://doi.org/10.1080/10888691.2015.1113879

Ryan, R. M., \& Deci, E. L. (2017). Self-determination theory: Basic psychological needs in motivation, development, and wellness. Guilford Press. 
Serido, J., Borden, L. M., \& Perkins, D. F. (2011). Moving beyond youth voice. Youth \& Society, 43(1), 44-63. https://doi.org/10.1177/0044118X09351280

Smith, C., Akiva, T., Arrieux, D., \& Jones, M. M. (2006). Improving quality at the point of service. New Directions for Youth Development, 112, 93-108. https://doi.org/10.1002/yd.195

Spencer, R., \& Rhodes, J. E. (2014). Growth-promoting relationships with children and youth. New Directions for Youth Development, 144, 59-72. https://doi.org/10.1002/yd.20113

Stewart, D. W., Shamdasani, P. N., \& Rook, D. W. (2007). Focus groups: Theory and practice (2 ${ }^{\text {nd }}$ ed.). Sage.

Subramaniam, A., \& Moncloa, F. (2010). Young people's perspectives on creating a "participationfriendly" culture. Children, Youth and Environments, 20(2), 25-45. https://doi.org/10.7721/chilyoutenvi.20.2.0025

Suleiman, A. B., Ballard, P. J., Hoyt, L. T., \& Ozer, E. J. (2019). Applying a developmental lens to youthled participatory action research: A critical examination and integration of existing evidence. Youth \& Society. https://doi.org/10.1177/0044118X19837871

Thomas, J., Larson, M., Solberg, V. S., \& Martin, J. (2017). Providing quality career development within youth development \& leadership programs (Issue 45). National Collaborative on Workforce and Disability for Youth. https://eric.ed.gov/?id=ED585183

Walker, K. C. (2011). The multiple roles that youth development program leaders adopt with youth. Youth \& Society, 43(2), 635-655. https://doi.org/10.1177/0044118X10364346

Walker, J., Marczak, M., Blyth, D., \& Borden, L. (2005). Designing youth development programs: Toward a theory of developmental intentionality. In J. L. Mahoney, R. W. Larson, \& J. S. Eccles (Eds). Organized activities as contexts of development: Extracurricular activities, after-school and community programs (pp. 399-418). Lawrence Erlbaum.

Witt, P. A., \& Caldwell, L. L. (Eds.) (2018). Youth development: Principles and practices in out-of-school time settings ( $2^{\text {nd }}$ ed.). Sagamore Venture Publishing.

Yohalem, N., \& Wilson-Ahlstrom, A. (2010). Inside the black box: Assessing and improving quality in youth programs. American Journal of Community Psychology, 45(3-4), 350-357. https://doi.org/10.1007/s10464-010-9311-3

Youth Speak Out Coalition, \& Zimmerman, K. (2007). Making space, making change: Models for youthled social change organizations. Children, Youth and Environments, 17(2), 298-314. https://doi.org/10.7721/chilyoutenvi.17.2.0298 